\title{
Review \\ The Emergence of Multidrug-Resistant Helicobacter pylori in Southeast Asia: A Systematic Review on the Trends and Intervention Strategies Using Antimicrobial Peptides
}

\author{
Asif Sukri ${ }^{1}\left(\mathbb{D}\right.$, Bruno S. Lopes $^{2}$ and Alfizah Hanafiah ${ }^{3, *}$ \\ 1 Integrative Pharmacogenomics Institute (iPROMISE), Universiti Teknologi MARA (UiTM), Selangor Branch, \\ Puncak Alam Campus, Puncak Alam 42300, Malaysia; mohdasifsukri@gmail.com \\ 2 Department of Medical Microbiology, School of Medicine, Medical Sciences and Nutrition, \\ University of Aberdeen, Aberdeen AB25 2ZD, UK; brunoldlopez@gmail.com \\ 3 Department of Medical Microbiology and Immunology, Faculty of Medicine, Universiti Kebangsaan \\ Malaysia, Kuala Lumpur 56000, Malaysia \\ * Correspondence: alfizah@ppukm.ukm.edu.my
}

\section{check for} updates

Citation: Sukri, A.; Lopes, B.S.; Hanafiah, A. The Emergence of Multidrug-Resistant Helicobacter pylori in Southeast Asia: A Systematic Review on the Trends and Intervention Strategies Using Antimicrobial Peptides. Antibiotics 2021, 10, 1061. https://doi.org/ 10.3390/antibiotics10091061

Academic Editors: Xiaolin Wei and Rebecca King

Received: 5 August 2021

Accepted: 30 August 2021

Published: 1 September 2021

Publisher's Note: MDPI stays neutral with regard to jurisdictional claims in published maps and institutional affiliations.

Copyright: (c) 2021 by the authors. Licensee MDPI, Basel, Switzerland. This article is an open access article distributed under the terms and conditions of the Creative Commons Attribution (CC BY) license (https:/ / creativecommons.org/licenses/by/ $4.0 /)$.

\begin{abstract}
The emergence of multidrug-resistant H. pylori poses a public healthcare threat, particularly in low- and middle-income countries. Recently, the World Health Organization has classified clarithromycin-resistant $H$. pylori as high priority in the research and discovery of novel antibiotics. This study was aimed to systematically review the prevalence of primary antibiotic resistance in H. pylori in Southeast Asian countries (SEAC) and to review current studies of antimicrobial peptides against $H$. pylori. We systematically searched through electronic databases of studies conducted on antimicrobial resistance of $H$. pylori in SEA countries. Furthermore, we searched articles that conducted studies on antimicrobial peptides, naturally occurring host's defense molecules, against H. pylori. After a series of screening processes, 15 studies were included in our systematic review. Our analysis revealed that primary resistance of $H$. pylori to metronidazole, clarithromycin, and levofloxacin were high in SEAC, although the primary resistance to amoxicillin and tetracycline remains low. Multidrug-resistant $H$. pylori are emerging in SE Asian countries. The antimicrobial peptides show promising antibacterial and antibiofilm activity against drug-resistant $H$. pylori. The research and discovery of antimicrobial peptides against $H$. pylori in SEAC will help in limiting the spread of antimicrobial resistance of H. pylori.
\end{abstract}

Keywords: Helicobacter pylori; low and middle-income countries; antimicrobial resistance; antimicrobial peptides; multidrug resistance; clarithromycin; metronidazole

\section{Introduction}

Helicobacter pylori is one of the most common infectious disease agents worldwide, with more than $50 \%$ of the world's population being infected with this pathogen, mostly in developing countries [1]. Transmission of $H$. pylori is still uncertain, but several studies have shown that close contact of a mother with a child during childhood is the main transmission route, apart from drinking contaminated water [2]. Since its discovery by Warren and Marshall almost three decades ago, it is now established that this bacterium orchestrates gastric carcinogenesis by producing multiple virulence factors that lead to peptic ulcer and gastric cancer [3]. Gastric cancer is still one of the most common cancers globally, with more than 1 million new cases reported yearly, leading to 768,793 deaths in 2020 alone [4]. Furthermore, gastric cancer patients are mainly detected at the advanced stage of cancer, where cancer prognosis is worse than that of detection at an early stage [5]. A high economic and mortality burden is associated with gastric cancer, with most cases occurring in developing countries where medical resources for early screening and patient management are limited [4]. Therefore, early screening of gastric cancer for detecting precancerous 
lesions for better prognosis and eradicating H. pylori are two essential strategies to prevent gastric cancer development.

Treatment of $H$. pylori includes administering proton pump inhibitors (PPI) coupled with multiple antibiotics through several treatment regimens. In the first-line triple therapy, PPI is administered with amoxicillin and clarithromycin. However, in areas where the clarithromycin resistance rate is higher than $15 \%$, triple therapy containing metronidazole or bismuth-containing quadruple therapy is recommended [6]. Nevertheless, the increasing rate of multiple-drug-resistant $H$. pylori has implications for the eradication of bacteria to prevent gastric diseases, including gastric cancer and ulcers [7]. The World Health Organization (WHO) has declared clarithromycin-resistant $H$. pylori a high priority in the research and development of novel antimicrobial discovery [8]. As such, an alarming concern of the increasing rate of antibiotic resistance presents urgency for the discovery of novel or alternative therapies for H. pylori. SEAC are home to more than 650 million people with diverse ethnicities and cultures. Most of these countries are mainly low-and middle-income countries, where medical resources are limited [9]. However, it is also home to diverse natural flora and fauna, with more than $20 \%$ of global plant and animal species, and where four out of twenty-five global biodiversity hotspots are found [10]. Antimicrobial peptides (AMP) are a small class of peptides that are part of an organism's innate immunity with an inhibitory effect against pathogens such as the inhibition of nucleotide and protein synthesis of pathogens, formation of the pore at the cell membrane, and the host's immunomodulation [11]. AMPs are good candidates for alternative therapies for the treatment of antibiotic-resistant infections and are broad-spectrum antimicrobial agents to which most bacteria evolution is slow. AMP has been isolated from multiple flora and fauna such as amphibians, fish, and plants [12]. Given that SEA has one of the world's greatest biodiversity hotspots, this region can be one in which AMP research and discovery can be conducted rapidly. The objective of this review was to systematically study antibiotic resistant in H. pylori in SEA and to summarize our current understanding of AMP and its role as an alternative therapeutic option for H. pylori infections.

\section{Results}

The systematic search through electronic databases resulted in 2417 articles, and an additional three articles were found by checking references of a previous systematic review. After title and abstract screening, 116 articles underwent full-text assessment (Figure 1). By applying inclusion and exclusion criteria, only 16 articles from 7 out of 10 SEA countries met the eligibility criteria for inclusion in this systematic review. After quality assessment, one article was excluded due to low quality (quality score $=3$ ), and the final number of articles included in this systematic review was 15 . The articles from countries that were included in this systematic review were as follows: Cambodia $(n=1)$, Indonesia $(n=1)$, Laos $(n=1)$, Malaysia $(n=3)$, Singapore $(n=1)$, Thailand $(n=5)$, and Vietnam $(n=3)$ and were published between 2011 to 2020. The patients recruited in the studies were diagnosed with symptoms of dyspepsia. The mean patient age in the included studies ranged from 38 to 55 years old. The methods employed to diagnose $H$. pylori infection in the included studies were bacterial culture, rapid urease test, molecular technique of polymerase chain reaction (PCR), and histopathological examination. For antibiotic resistance testing, a molecular technique and a culture-based method, namely the E-test and the agar dilution assay, were used (Table 1). 


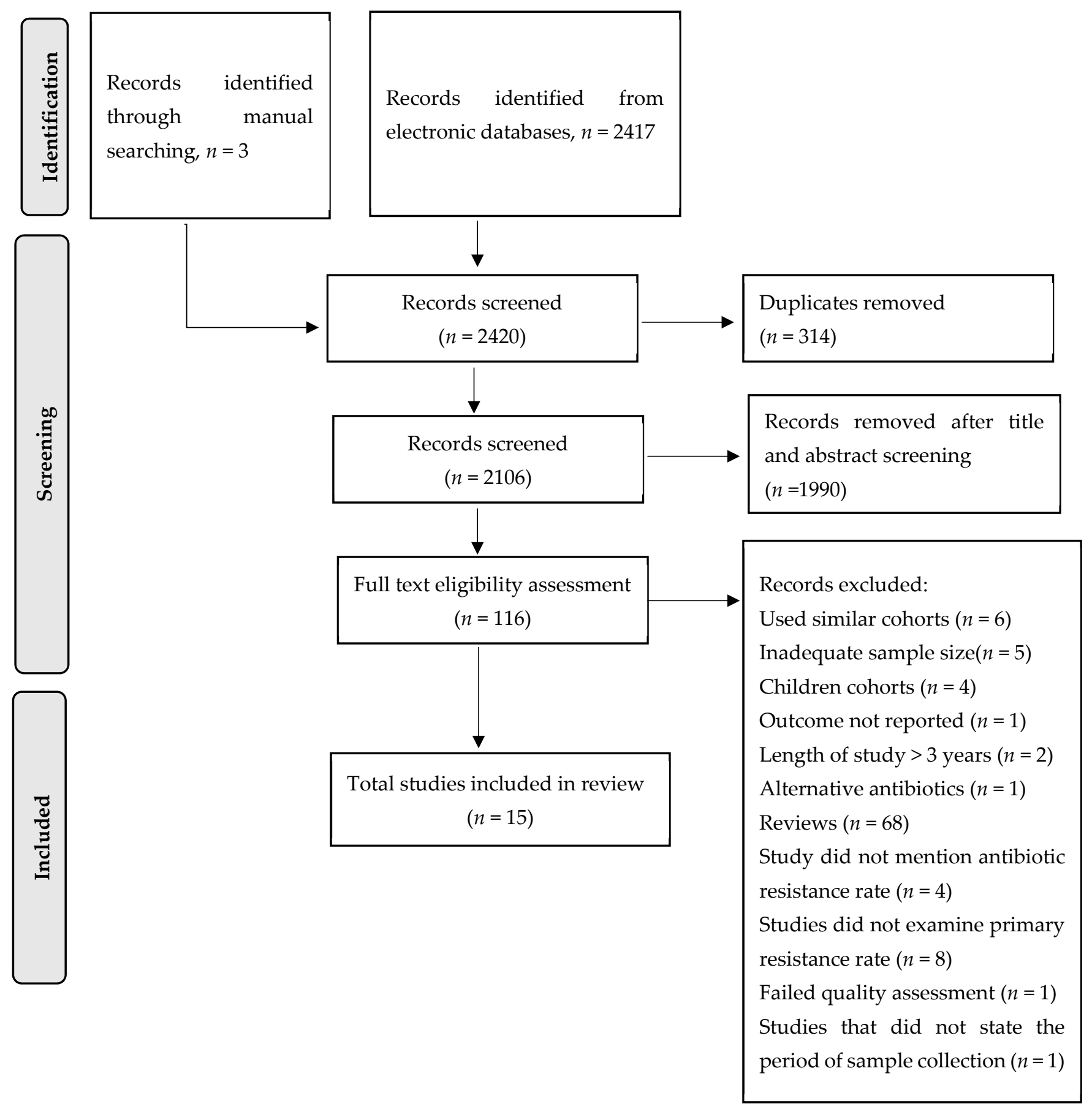

Figure 1. Flow chart of study selection. Exclusion criteria were: (1) Studies that measured the prevalence of alternative antibiotics for $H$. pylori treatment, (2) studies that reported prevalence results using $<50$ isolates for culture method or $<50 \mathrm{H}$. pylori positive gastric biopsies for nucleic acid-based method, (3) studies that only reported percentage of resistance rates with no description of the number of isolates used, (4) studies with no time frame of sample collection, (5) studies that clustered prevalence rates data more than three years, (6) studies that failed to state the percentage of primary antibiotic resistance in $\mathrm{H}$. pylori isolates examined, and (7) studies that only examined the prevalence of resistance rate of secondary isolates. 
Table 1. List of studies included in the systematic review.

\begin{tabular}{|c|c|c|c|c|c|c|c|c|}
\hline Author & $\begin{array}{c}\text { Year } \\
\text { Published }\end{array}$ & $\begin{array}{c}\text { Patient's } \\
\text { Age (Mean } \\
\text { in Years) }\end{array}$ & Country & $\begin{array}{c}\text { No. } \\
\text { ofPatients }\end{array}$ & $\begin{array}{c}\text { HP } \\
\text { Diagnostic } \\
\text { Test }\end{array}$ & $\begin{array}{l}\text { Patients' } \\
\text { Diseases }\end{array}$ & $\begin{array}{c}\text { Antibiotic } \\
\text { Resistance } \\
\text { Method }\end{array}$ & Ref. \\
\hline $\begin{array}{c}\text { Auttajaroon } \\
\text { et al. }\end{array}$ & 2019 & 54.5 & Thailand & 93 & $\begin{array}{l}\text { RUT and } \\
\text { culture }\end{array}$ & $\begin{array}{l}\text { Functional } \\
\text { dyspepsia }\end{array}$ & E-test & [13] \\
\hline $\begin{array}{l}\text { Vilaichone } \\
\text { et al. }\end{array}$ & 2017 & 55.9 & Thailand & 148 & $\begin{array}{l}\text { RUT and } \\
\text { culture }\end{array}$ & Dyspepsia & E-test & [14] \\
\hline $\begin{array}{l}\text { Vilaichone } \\
\text { et al. }\end{array}$ & 2016 & 46.7 & Thailand & 291 & $\begin{array}{l}\text { RUT and } \\
\text { culture }\end{array}$ & Dyspepsia & E-test & [15] \\
\hline $\begin{array}{l}\text { Vilaichone } \\
\text { et al. }\end{array}$ & 2011 & 49.1 & Thailand & 412 & $\begin{array}{l}\text { Culture } \\
\text { and CLO } \\
\text { test }\end{array}$ & Dyspepsia & E-test & [16] \\
\hline $\begin{array}{l}\text { Tongtawee } \\
\text { et al. }\end{array}$ & 2015 & 45.2 & Thailand & 300 & $\begin{array}{l}\text { HPE and } \\
\text { RUT }\end{array}$ & Dyspepsia & $\begin{array}{l}\text { Molecular } \\
\text { technique }^{\mathrm{a}}\end{array}$ & [17] \\
\hline Tuan et al. & 2019 & 45.3 & Cambodia & 206 & Culture & NA & $\begin{array}{l}\text { Agar } \\
\text { dilution } \\
\text { assay }\end{array}$ & [18] \\
\hline $\begin{array}{l}\text { Miftahussurur } \\
\text { et al. }\end{array}$ & 2016 & $\begin{array}{c}49.6 \text { (male) } \\
\text { and } 48.9 \\
\text { (female) }\end{array}$ & Indonesia & 849 & $\begin{array}{l}\text { Culture } \\
\text { and HPE }\end{array}$ & Dyspepsia & E-test & [19] \\
\hline $\begin{array}{c}\text { Vannarath } \\
\text { et al. }\end{array}$ & 2016 & 46 & Laos & 329 & $\begin{array}{l}\text { CLO and } \\
\text { HPE }\end{array}$ & Dyspepsia & $\begin{array}{l}\text { Molecular } \\
\text { technique }^{\mathrm{a}}\end{array}$ & [20] \\
\hline $\begin{array}{l}\text { Hanafiah } \\
\text { et al. }\end{array}$ & 2019 & 52.41 & Malaysia & 288 & $\begin{array}{l}\text { Culture, } \\
\text { HPE and } \\
\text { RUT }\end{array}$ & $\begin{array}{c}\text { Chronic } \\
\text { dyspepsia }\end{array}$ & E-test & [21] \\
\hline Goh et al. & 2011 & 50.5 & Malaysia & 90 & Culture & NA & E-test & [22] \\
\hline Ahmad et al. & 2011 & NA & Malaysia & 777 & $\begin{array}{l}\text { Culture, } \\
\text { RUT and } \\
\text { HPE }\end{array}$ & $\begin{array}{c}\text { Gastritis, } \\
\text { peptic ulcer } \\
\text { and gastric } \\
\text { cancer }\end{array}$ & E-test & [23] \\
\hline Ang et al. & 2015 & 48 & Singapore & 462 & $\begin{array}{l}\text { UBT, RUT } \\
\text { and HPE }\end{array}$ & NA & $\begin{array}{l}\text { Agar } \\
\text { dilution } \\
\text { method }\end{array}$ & [24] \\
\hline Dang et al. & 2020 & 38.3 & Vietnam & 153 & $\begin{array}{l}\text { Culture } \\
\text { and RUT }\end{array}$ & $\begin{array}{l}\text { Chronic } \\
\text { gastritis }\end{array}$ & E-test & [25] \\
\hline Binh et al. & 2013 & $\begin{array}{c}47.3 \text { (male) } \\
\text { and } 42.3 \\
\text { (female) }\end{array}$ & Vietnam & NA & Culture & Dyspepsia & E-test & [26] \\
\hline Phan et al. & 2015 & 44.1 & Vietnam & 92 & Culture & Dyspepsia & E-test & [27] \\
\hline
\end{tabular}

a Point mutation of A2143/2142CG in 23S rRNA to detect clarithromycin resistance; Abbreviations HP: H. pylori; RUT: Rapid urease test; HPE: Histopathological examination; CLO: Campylobacter-like organism; E-test: Epsilometer test; UBT: Urea breath test; CLA: Clarithromycin; MET: Metronidazole; LEVO: Levofloxacin; AMX: Amoxicillin; TET: Tetracycline; NA: Not available.

\subsection{Summary of Primary Antibiotic Resistance Rate in H. pylori}

\subsubsection{Clarithromycin Resistance}

From our systematic search, 15 studies from SEA countries examined primary clarithromycin resistance in $\mathrm{H}$. pylori (Table 2). In Thailand, clarithromycin resistance ranged from as low as $5.6 \%$ to as high as $76.2 \%$ for four studies conducted from 2013 to 2017 . Of the four studies, the trend of clarithromycin resistance in Thailand was $5.6 \%$ in 2013 [15], $76.2 \%$ in 2014 to 2015 [17], $2 \%$ in 2016 [14], and $12.9 \%$ in 2017 [13]. The variability of clarithromycin resistance in $\mathrm{H}$. pylori isolated in Thailand can be attributed to locations where the sampling was conducted and the type of diagnostic test used to assess antibiotic 
resistance. The prevalence of clarithromycin resistance was as high as $76.2 \%$ from the samples collected in the Northeast region of the country and molecular detection was used instead of culture-based detection [17], while the prevalence was less than $13 \%$ from the samples collected from the Mountain people [15], namely Karen, Thai, and Hmong people, the Pathumthani region [13], and the Chiangrai province [14] using culture-based diagnosis. In Cambodia, one study conducted in the country revealed primary clarithromycin resistance of $\mathrm{H}$. pylori as $25.5 \%$ in 2015 [18] while in Indonesia, the clarithromycin resistance rate was $9.1 \%$ from 2012 to 2015 [19]. In Laos, the clarithromycin resistance rate was $12.6 \%$ from 2010 to 2012 [20]. Three studies examined primary clarithromycin resistance in $H$. pylori in Malaysia, in which the resistance rate showed an increasing trend from 2004 to 2015. From 2004 to 2009, the clarithromycin resistance rate was <2.1\% [22,23]. However, the resistance rate increased to $12.2 \%$ from 2014 to 2015 [21]. Meanwhile, in Singapore, a study published in 2015 revealed the primary clarithromycin resistance was $17.9 \%$ [24]. In Vietnam, the primary resistance rate of clarithromycin increased from $33 \%$ in 2008 [26] to $34.2 \%$ from 2012 to 2014 [27] and $66.1 \%$ from 2014 to 2016 [25].

Table 2. Primary antibiotic resistance rates of H. pylori.

\begin{tabular}{|c|c|c|c|c|c|c|c|c|c|c|}
\hline \multirow{2}{*}{ Author } & \multirow{2}{*}{$\begin{array}{l}\text { Period of } \\
\text { Sample } \\
\text { Collection }\end{array}$} & \multirow{2}{*}{ Country } & \multirow{2}{*}{$\begin{array}{c}\text { No. of } \\
\text { HP } \\
\text { Isolates }\end{array}$} & \multicolumn{5}{|c|}{ Primary Antibiotic Resistance Rate, \% } & \multirow{2}{*}{$\begin{array}{c}\text { MDR Rate, \% } \\
\text { (No. of } \\
\text { Isolates) }\end{array}$} & \multirow{2}{*}{ Reference } \\
\hline & & & & CLA & MET & LEVO & AMX & TET & & \\
\hline $\begin{array}{l}\text { Auttajaroon } \\
\text { et al. }\end{array}$ & 2017 & Thailand & $93^{\mathrm{a}}$ & 12.9 & 62.8 & - & - & - & - & {$[13]$} \\
\hline $\begin{array}{l}\text { Vilaichone } \\
\text { et al. }\end{array}$ & 2016 & Thailand & 50 & 2 & 26 & 22 & 0 & 0 & $4 \%(2 / 50)$ & {$[14]$} \\
\hline $\begin{array}{l}\text { Vilaichone } \\
\text { et al. }\end{array}$ & 2013 & Thailand & 124 & 5.6 & 71.8 & 19.4 & 0.8 & 0 & $\begin{array}{c}21.8 \% \\
(27 / 124)\end{array}$ & [15] \\
\hline $\begin{array}{l}\text { Vilaichone } \\
\text { et al. }\end{array}$ & 2008-2010 & Thailand & 100 & - & 30 & - & - & - & - & [16] \\
\hline $\begin{array}{l}\text { Tongtawee } \\
\text { et al. }\end{array}$ & 2014-2015 & Thailand & $300^{b, *}$ & $76.2^{c}$ & - & - & - & - & - & [17] \\
\hline Tuan et al. & 2015 & Cambodia & 55 & 25.5 & 96.4 & 67.3 & 9.1 & 0 & $76.4 \%(42 / 55)$ & [18] \\
\hline $\begin{array}{l}\text { Miftahussurur } \\
\text { et al. }\end{array}$ & 2012-2015 & Indonesia & 77 & 9.1 & 46.8 & 31.2 & 5.2 & 2.6 & - & [19] \\
\hline $\begin{array}{l}\text { Vannarath } \\
\text { et al. }\end{array}$ & 2010-2012 & Laos & $119^{b, * *}$ & 12.6 & - & - & - & - & - & [20] \\
\hline $\begin{array}{l}\text { Hanafiah } \\
\text { et al. }\end{array}$ & 2014-2015 & Malaysia & $59^{d}$ & 12.2 & 56.1 & 17.1 & 0 & 0 & $7.4 \%(2 / 27)$ & [21] \\
\hline Goh et al. & 2009 & Malaysia & 90 & 0 & 75.5 & 0 & 0 & - & - & [22] \\
\hline $\begin{array}{l}\text { Ahmad } \\
\text { et al. }\end{array}$ & 2004-2007 & Malaysia & 187 & 2.1 & 36.9 & - & 0 & 0 & $2.1 \%(4 / 187)$ & [23] \\
\hline Ang et al. & 2011-2014 & Singapore & 106 & 17.9 & 48.1 & - & 4.7 & - & $7.5 \%(8 / 106)$ & [24] \\
\hline $\begin{array}{l}\text { Dang } \\
\text { et al. }\end{array}$ & 2014-2016 & Vietnam & $153^{d}$ & 66.1 & - & 38.1 & - & - & $\begin{array}{l}30.7 \% \text { e } \\
(47 / 153)\end{array}$ & [25] \\
\hline Binh et al. & 2008 & Vietnam & 103 & 33 & 69.9 & 18.4 & 0 & 5.8 & $\begin{array}{c}24.3 \% \\
(25 / 103) \\
\end{array}$ & [26] \\
\hline $\begin{array}{l}\text { Phan } \\
\text { et al. }\end{array}$ & 2012-2014 & Vietnam & $92^{d}$ & 34.2 & 75.3 & 35.6 & 0 & - & $\begin{array}{l}50.7 \%(37 / 73) \\
\text { for primary } \\
\text { resistance and } \\
78.9 \%(15 / 19) \\
\text { for secondary } \\
\text { resistance }\end{array}$ & [27] \\
\hline
\end{tabular}

a Metronidazole resistance was performed in 43 isolates while clarithromycin resistance was performed in 70 isolates; ${ }^{\mathrm{b}}$ indicates antibiotic susceptibility test was conducted directly on gastric biopsies using molecular technique without isolation of the bacteria; ${ }^{\mathrm{c}} 76.2 \%$ was derived from the number of isolates that harbored both mutation and wildtype variants in $23 \mathrm{~S}$ rRNA sequence; ${ }^{\mathrm{d}}$ Total number of isolates were derived from primary and secondary isolates. The primary resistance rates were recalculated using total primary isolates as denominator; ${ }^{\mathrm{e}} \mathrm{Multidrug}$ resistance from both primary and secondary isolates; ${ }^{*}$ DNA was extracted from all 300 gastric biopsies for molecular detection of antibiotic resistance, ${ }^{* *}$ DNA was extracted from $119 / 329$ patients for molecular detection of antibiotic resistance. Abbreviations: HP: $H$. pylori; CLA: Clarithromycin; MET: Metronidazole; LEVO: Levofloxacin; AMX: Amoxicillin; TET: Tetracycline; -: Not available. 


\subsubsection{Metronidazole Resistance}

Fifteen studies examined the primary resistance rate of metronidazole resistance in H. pylori, of which all studies found the resistance rate was high ( $>15 \%$ resistance rate). In Thailand, the metronidazole resistance rate showed an increasing trend from $30 \%$ between 2008 to 2010 [16] to $71.8 \%$ in 2013 [18] and 62.8\% in 2017 [13]. A similar trend was also observed in Malaysia, in which the metronidazole resistance rate ranged from $36.9 \%$ [23] to $75.5 \%$ [22] from 2004 to 2009 and $56.1 \%$ between 2014 to 2015 [21]. In Vietnam, the trend of the metronidazole resistance rate was $69.9 \%$ in 2008 [26] and increased to $75.3 \%$ from 2012 to 2014 [27]. In Singapore, the metronidazole resistance rate observed was $48.1 \%$ from 2011 to 2014 [24]. The resistance rate was alarmingly high in Laos, in which a recent observation in 2015 revealed the rate was $96.4 \%$ [18]. Meanwhile, in Indonesia, the resistance rate of clarithromycin resistance in H. pylori was 46.8\% from 2012 to 2015 [19].

\subsubsection{Levofloxacin Resistance}

The primary levofloxacin resistance rate was observed to increase from year to year in Thailand, in which the resistance rate increased from 19.4\% [15] in 2013 and 22\% in 2016 [14]. Meanwhile, high resistance rate of levofloxacin was observed in Cambodia [18] and Indonesia [19] (67.3\% and 31.2\%, respectively). In Malaysia, the primary resistance rate of levofloxacin was high at $17.1 \%$ from 2014 to 2015 [21]. The trend of levofloxacin resistance rate increased in Vietnam from 18.4\% in 2008 [26], 35.6\% from 2012 to 2014 [27] to $38.1 \%$ from 2014 to 2016 [25].

\subsubsection{Amoxicillin Resistance}

Our analysis revealed that the primary amoxicillin resistance rate of H. pylori in SEAC is still low. No H. pylori isolate was reported to be resistant to amoxicillin in Malaysia [21-23] while in Thailand, the resistance rate of $H$. pylori to amoxicillin was reported to be $0.8 \%$ in a study conducted from samples collected in 2013 [15] while no amoxicillin resistance isolate was observed in another study [14]. In Cambodia and Indonesia, rates of amoxicillin resistant H. pylori were 9.1\% [18] and 5.2\% [19], respectively. In Singapore, the resistance rate was 4.7\% from 2011 to 2014 [24] while in Vietnam, the resistance rate was not observed in the study conducted from 2012 to 2014 [27].

\subsubsection{Tetracycline Resistance}

Similar to the amoxicillin resistance rate, the tetracycline resistance rate in most SEACs is low. No reports of tetracycline-resistant H. pylori were observed in Thailand and Malaysia, while in Indonesia, the resistance rate was 2.8\% [19]. However, in Vietnam, the tetracycline resistance rate was reported to be $5.8 \%$ in 2008 [26].

\subsubsection{Multidrug Resistance Rate of $H$. pylori}

The multidrug resistance rate of $H$. pylori reported in SEA countries varied across all countries examined. In Malaysia, the reported multidrug resistance was still low, but than increasing resistance rate was observed. Of the two studies that reported a multidrug resistance rate in Malaysia, the resistance rates were 2.1\% from 2004 to 2007 [23] but increased to $7.4 \%$ from 2014 to 2015 [21]. This finding suggests that there is an increase in multidrug-resistant $H$. pylori in Malaysia. Similarly, Singapore, the neighboring country of Malaysia, had a multidrug resistance rate of $7.5 \%$ between 2011 to 2014 [24]. Of the two studies that reported multidrug resistance rate in Thailand, one study found that the rate was $4 \%$ in 2016 [14] and 21.8\% in 2013 [15]. Contrary to Malaysia, Thailand, and Singapore, the multidrug resistance rates of $H$. pylori in Vietnam and Cambodia were high. The rate of multidrug-resistant $H$. pylori in Vietnam increased from $24.3 \%$ in 2008 [26] to $30.7 \%$ from 2014 to 2016 [25]. Meanwhile, the multidrug resistance rate of $H$. pylori strains in Cambodia was extremely high at $76.4 \%$ [18], of which $40 \%$ were resistant to levofloxacin and metronidazole, $7.3 \%$ were resistant to clarithromycin and metronidazole, $9.1 \%$ were 
resistant to metronidazole, levofloxacin, and amoxicillin, and $18.2 \%$ were resistant to clarithromycin, levofloxacin, and metronidazole.

\subsection{A Review on Intervention Strategy Using AMP}

Given the high resistance rates of $H$. pylori to critically important antibiotics in this region, we searched the database on intervention strategies of $H$. pylori treatment using AMP. AMPs are small peptides that have been demonstrated to possess broad-spectrum activity against bacteria. They are usually isolated from natural sources such as the skin of amphibians and venoms. The SEACs are a region with high biological diversity and lush tropical forests where the sources for discovery and research on novel antimicrobial drugs against $H$. pylori can be further explored. As such, we aimed to summarize the studies conducted on AMPs against $H$. pylori for understanding the current progress in research. Table 3 summarizes the studies conducted on AMPs against H. pylori. We found that all the studies conducted demonstrated antibacterial activity of AMPs against $H$. pylori and all studies employed synthetically synthesized AMPs (Table 3). Five AMPs, namely cathelicidin [28], bicarinalin [29], odorranain-HP [30], tilapia Piscidin 4 [31], and pleurain-A [32], were initially identified from natural sources and then synthesized synthetically in the laboratory. Notably, some AMPs, including cathelicidin-like AMP [33], bicarinalin [29], fusion human neutrophil peptide 1 [34], and epinecidin 1 [35], showed bactericidal activity against drug-resistant $H$. pylori. The mechanism of bactericidal and bacteriostatic AMPs includes the perturbation, permeabilization, and rupture of the bacterial cell membrane (Table 3). In addition, cathelicidin from humans and mice exhibited antibiofilm activity against $H$. pylori and protected the animal model from inflammation induced by H. pylori [28]. A study conducted by Jiang et al. [33] found that a cathelicidin-like peptide, namely $\mathrm{Cbf}-\mathrm{K}_{16}$, reduced intercellular and intracellular activity of $H$. pylori and decreased H. pylori colonization in animal model. Furthermore, helix-coil conformation transitional antimicrobial polypeptides demonstrated bactericidal activity against $H$. pylori at low $\mathrm{pH}$, suggesting its potential for use in human. Besides that, the peptide demonstrated low toxicity in animal study and an examined stomach, suggesting that the peptide is worthy to be evaluated in clinical trials [36].

Table 3. Summary of studies conducted on antimicrobial peptides against $H$. pylori.

\begin{tabular}{|c|c|c|c|c|c|}
\hline Author & Year & Name of AMP & Source & $\begin{array}{l}\text { Finding on Antibacterial Activity } \\
\text { against } H \text {. pylori }\end{array}$ & Reference \\
\hline Zhang et al. & 2016 & Cathelicidin & Mouse and human & $\begin{array}{l}\text { Bactericidal activity against } \\
\text { clarithromycin-resistant } H \text {. pylori; } \\
\text { anti-biofilm activity against H. pylori } \\
\text { SS1 strain; protected mouse from } H \text {. } \\
\text { pylori orchestrated inflammation and } \\
\text { reduced } H \text {. pylori colonization }\end{array}$ & [28] \\
\hline Guzman et al. & 2018 & Bicarinalin & $\begin{array}{l}\text { Synthetically } \\
\text { synthesized in lab (anti } \\
\text { venom Tetramorium } \\
\text { bicarinatum) }\end{array}$ & $\begin{array}{c}\text { Perturbation of membrane } \\
\text { permeability against drug-resistant } \\
\text { H. pylori }\end{array}$ & [29] \\
\hline Chen et al. & 2007 & Odorranain-HP & $\begin{array}{c}\text { Synthetically } \\
\text { synthesized in lab } \\
\text { (Diskless odorous frog, } \\
\text { Odorrana graham) }\end{array}$ & $\begin{array}{l}\text { Showed antimicrobial activity against } \\
\text { H. pylori (MIC of } 20 \mu \mathrm{g} / \mathrm{mL} \text { ) }\end{array}$ & {$[30]$} \\
\hline Narayana et al. & 2015 & $\begin{array}{l}\text { Tilapia Piscidin } 4 \\
\text { (TP4) }\end{array}$ & $\begin{array}{c}\text { Synthetically } \\
\text { synthesized in lab } \\
\text { (Nile tilapia, } \\
\text { Oreochromis niloticus) }\end{array}$ & $\begin{array}{l}\text { Demonstrated potential lytic activity } \\
\text { against } H \text {. pylori surface membrane; } \\
\text { disrupted the bacterial cell membrane }\end{array}$ & [31] \\
\hline
\end{tabular}


Table 3. Cont.

\begin{tabular}{|c|c|c|c|c|c|}
\hline Author & Year & Name of AMP & Source & $\begin{array}{l}\text { Finding on Antibacterial Activity } \\
\text { against } H \text {. pylori }\end{array}$ & Reference \\
\hline Wang et al. & 2007 & Pleurain-A & $\begin{array}{c}\text { Synthetically } \\
\text { synthesized in lab } \\
\text { (Yunnan frog, Rana } \\
\text { pleuraden) }\end{array}$ & $\begin{array}{l}\text { Inhibited growth of H. pylori in vitro } \\
\qquad(30 \mu \mathrm{g} / \mathrm{mL})\end{array}$ & {$[32]$} \\
\hline Jiang et al. & 2020 & $\begin{array}{l}\text { Cbf- } \mathrm{K}_{16} \\
\text { (cathelicidin-like } \\
\text { AMP) }\end{array}$ & $\begin{array}{l}\text { Synthetically } \\
\text { synthesized }\end{array}$ & $\begin{array}{l}\text { Demonstrated bactericidal activity } \\
\text { against clarithromycin- and } \\
\text { amoxicillin-resistant } H . \text { pylori; } \\
\text { reduced intercellular and intracellular } \\
\text { drug-resistant } H \text {. pylori in cell culture; } \\
\text { showed increased membrane } \\
\text { permeation in drug-resistant } H . p y l o r i\end{array}$ & [33] \\
\hline Zhang et al. & 2018 & $\begin{array}{l}\text { Fusion human } \\
\text { neutrophil } \\
\text { peptide } 1\end{array}$ & $\begin{array}{l}\text { Expression system } \\
\text { in yeast }\end{array}$ & $\begin{array}{l}\text { Eradication of wild type and } \\
\text { drug-resistant } H \text {. pylori in } \\
\text { animal model }\end{array}$ & {$[34]$} \\
\hline Narayana et al. & 2015 & Epinecidin-1 & $\begin{array}{l}\text { Synthetically } \\
\text { synthesized in lab }\end{array}$ & $\begin{array}{l}\text { Showed bactericidal activity against } \\
\text { drug-resistant } H \text {. pylori and } \\
\text { modulated immune response in } \\
\text { mouse-infected } H \text {. pylori for } \\
\text { bacterial clearance }\end{array}$ & [35] \\
\hline Xiong et al. & 2017 & $\begin{array}{l}\text { Helix-coil } \\
\text { conformation } \\
\text { transitional } \\
\text { antimicrobial } \\
\text { polypeptides }\end{array}$ & $\begin{array}{l}\text { Synthetically } \\
\text { synthesized in lab }\end{array}$ & $\begin{array}{l}\text { Displayed bactericidal activity } \\
\text { against } H \text {. pylori at low } \mathrm{pH} \text {, both } \\
\text { in vitro and in vivo }\end{array}$ & [36] \\
\hline Zhang et al. & 2015 & Pexiganan & $\begin{array}{l}\text { Synthetically } \\
\text { synthesized in lab }\end{array}$ & $\begin{array}{c}\text { Inhibited the growth of } H . \text { pylori (MIC } \\
=4 \mu \mathrm{g} / \mathrm{mL}) ; \text { decreased } H \text {. pylori } \\
\text { colonization in animal model }\end{array}$ & [37] \\
\hline Zhang et al. & 2017 & Fusion PGLa-AM1 & $\begin{array}{l}\text { Synthetically } \\
\text { synthesized in lab }\end{array}$ & $\begin{array}{l}\text { Showed bactericidal activity against } \\
\text { H. pylori in vitro and clearance of the } \\
\text { bacteria in vivo }\end{array}$ & [38] \\
\hline $\begin{array}{l}\text { Makobongo } \\
\text { et al. }\end{array}$ & 2012 & $\mathrm{C}_{12} \mathrm{~K}-2 \beta_{12}$ & $\begin{array}{l}\text { Synthetically } \\
\text { synthesized in lab }\end{array}$ & $\begin{array}{l}\text { Ruptured } H \text {. pylori surface membrane } \\
\text { for bactericidal effect; reduced } \\
\text { colonization of } H \text {. pylori in } \\
\text { gerbil model }\end{array}$ & [39] \\
\hline Rigano et al. & 2012 & Tomato defensin & $\begin{array}{c}\text { Synthetically } \\
\text { synthesized in lab }\end{array}$ & $\begin{array}{l}\text { Showed antibacterial activity against } \\
\text { H. pylori at MIC: } 15 \mu \mathrm{g} / \mathrm{mL}\end{array}$ & [40] \\
\hline Iwahori et al. & 1997 & Magainin 2 analog & $\begin{array}{l}\text { Synthetically } \\
\text { synthesized in lab }\end{array}$ & Inhibited growth of $H$. pylori in vitro & [41] \\
\hline
\end{tabular}

Abbreviations: AMP: Antimicrobial peptide; MIC: Minimum inhibitory concentration.

\section{Discussion}

This systematic review consists of the studies conducted in the SEA region in countries with a diverse ethnic background, culture, and socioeconomic status. Our systematic review revealed that primary resistance of metronidazole in the SEA region is high with a more than $15 \%$ threshold while the primary resistance to clarithromycin varies according to the country, i.e., high in Singapore, Cambodia, and Vietnam, medium in Malaysia, and still low in Indonesia. In countries such as Thailand and Laos, resistance rates to clarithromycin are increasing and would exceed the threshold of $15 \%$ if the intervention strategy is not implemented. From the data published, resistance rates to levofloxacin also appeared to be high ( $>15 \%)$ in all the SEA countries, with the rate observed to be as high as $>60 \%$ in Cambodia. Meanwhile, the resistance rates of $H$. pylori to amoxicillin and tetracycline are still low, with Malaysia reporting no cases of amoxicillin- and tetracycline-resistant $H$. 
pylori (Table 2). However, the amoxicillin- and tetracycline-resistant H. pylori have been reported in Indonesia and Cambodia, suggesting the emergence of $H$. pylori resistant to both antibiotics in these countries. Our findings are consistent with previous systematic reviews conducted by Savoldi et al. [7], which found that the resistance rates of H. pylori to metronidazole, clarithromycin, and levofloxacin are high in the SEA region. A similar systematic review also revealed high resistance rates of metronidazole in other parts of the world, including the Americas region, the European region, the Eastern Mediterranean region, and the Western Pacific region. Kuo et al. [42] also found an increasing rate of clarithromycin and metronidazole resistance in $H$. pylori in the Asian Pacific region. The rate of metronidazole resistance in SEA countries was observed to be very high (26-96.4\%) in all SEA countries included in this systematic review. Metronidazole is used for treatments including parasitic infections, oral infections, gynecological infections, bone and joint infections, septicemia, and endocarditis [43], and is one of the drugs recommended as a first-line therapy in the SEA H. pylori management consensus [44]. The high resistance rate of metronidazole in this region could not be ascertained, although excessive use of the antibiotics and non-compliance among patients in treatment regimens are factors associated with the rising antibiotic resistance rate [45]. Trends of clarithromycin resistance also show a sharp increase from year to year in Malaysia, with $<2.1 \%$ from 2004-2009 [22,23] to as high as $12.2 \%$ in 2014-2015 [21]. Vietnam also showed a sharp increase of clarithromycin resistance from $33 \%$ in 2008 [26] to $72.6 \%$ from 2014-2016 [25] while the trend in Thailand fluctuated from year to year. The trend of antimicrobial resistance rates in other countries could not be assessed due to a lack of studies conducted on antimicrobial resistance in H. pylori. This factor could be due to the difficulty of culturing H. pylori in the laboratory and the high cost of performing nucleic acid-based technique in the SEA region, which mostly consist of low- and middle-income countries. The Maastricht V/Florence Consensus Report suggests that primary treatment consisting of clarithromycin should be abandoned if the resistance rate to clarithromycin in the region exceeds $15 \%$, and quadruple therapy should be administered instead for successful eradication of H. pylori [6]. In the SEA region, the ASEAN Bangkok Consensus Report in 2016 recommends triple therapy consisting of clarithromycin as a first-line regimen for 14 days, provided that the prevalence of clarithromycin resistance in the area is less than $15 \%$. However, the triple therapy consisting of clarithromycin should be replaced with quadruple therapy when clarithromycin resistance rate exceeds $15 \%$ [44]. A systematic review and meta-analysis on the impact of eradication regimens in the areas with high clarithromycin and metronidazole resistance reveals that sequential therapy is more effective in eradicating H. pylori than that of prolonged 14-day triple therapy, while there was no difference observed between sequential and 14-day triple therapy in the areas with high metronidazole resistance [46]. While prevalence data of clarithromycin is known in some SEA countries, the prevalence in other countries is unknown. This will complicate the treatment options for H. pylori in these regions. Findings from our systematic review reveals that clarithromycin resistance in SEA countries is increasing. Taken together, these results suggest that the primary treatment consisting of quadruple therapy or sequential therapy must be administered to $H$. pylori-infected patients in SEA countries with high prevalence of clarithromycin resistance, provided clinical data of patients are available prior to the administration. Besides clarithromycin resistance in $H$. pylori, clinical factors that contribute to first-line treatment failure also include the patient's non-compliance during therapy period, the patient's age (eradication was more successful in older patients), and the type of ulcer, in which eradication was significantly more successful in duodenal ulcers compared to gastric ulcers, which should be taken into consideration before switching to quadruple treatment [47].

In our systematic review, we also found an increasing rate of multidrug-resistant $H$. pylori in the SEA countries examined. In Cambodia, the resistance rate of multidrug-resistant H. pylori was alarmingly high at 76.4\% [18], suggesting the urgency of an intervention strategy in this country. The multidrug-resistance of H. pylori in Vietnam was also high and increased from year to year $[25,26]$, while the trend was also observed in Malaysia, 
where the prevalence of multidrug-resistant $H$. pylori increased from year to year although the resistance rate was still low [21]. Similar to Malaysia, the multidrug-resistant $H$. pylori observed in Singapore [24] was also low while the rate in Thailand fluctuated from year to year $[14,15]$. Some studies in our systematic review did not report the prevalence of multidrug-resistant $H$. pylori; hence we were unable to conclude. However, we hypothesize that the resistance rates of $H$. pylori to multiple drugs are increasing in this region based on the available data from the countries that had conducted study on the surveillance rate of multidrug-resistant $H$. pylori in their respective countries. As such, we suggest for future studies to include the prevalence of multidrug-resistant $H$. pylori when reporting the surveillance of antimicrobial resistance in $\mathrm{H}$. pylori.

As the emergence of antimicrobial resistance in $\mathrm{H}$. pylori to important antibiotics keeps increasing, WHO has classified clarithromycin-resistant $H$. pylori as a high-priority pathogen in the research and discovery of novel antibiotics [8]. AMPs have emerged as a new therapeutic option for the treatment of bacterial infection as they possess antimicrobial spectrum characteristic against bacteria. Most antimicrobial peptides have been isolated from natural sources, which suggest that the SEA region can be a hotspot for the research and discovery of new AMPs [11]. As such, we narratively summarized the research and discovery of AMPs against $H$. pylori. While the results of AMPs against drug-resistant $H$. pylori are promising and effective, we found that the study of AMPs against $H$. pylori are still lacking globally and there was no study conducted on AMPs against $H$. pylori in SEAC. Furthermore, our review also found that the clinical trial of AMP against $H$. pylori has yet to be conducted and all studies were either limited to animal or cell culture investigations. The challenges in the application of antimicrobial peptides for treatment include the costeffectiveness of the novel drug to the economic health and the concern of toxicity associated with AMP [12]. As the SEA region consists of mostly low- and middle-income countries, the greatest challenge is the cost of AMP synthesis and whether it is economically cost-effective for the general population in this region. However, the research on AMP in the SEA region is worth being explored further as this region is rich in tropical biodiversity, a source for new antimicrobial peptide discovery.

The strength of our systematic review on the primary antibiotic resistance of $H$. pylori includes the examination of the trend of resistance rate in the SEA region that consists mostly of low- and middle-income countries. Our systematic review also informs policymakers regarding the alarming rate of $H$. pylori resistance to essential antibiotics such as clarithromycin and metronidazole in this region, suggesting an urgency for an intervention program. Furthermore, we presented a brief narrative review on the progress of AMP against $H$. pylori research worldwide with paucity of the research in the SEA region where the biodiversity hotspot exists. However, our systematic review is constrained by a lack of studies conducted on the surveillance of antimicrobial resistance in H. pylori in the SEA region, suggesting the need for future surveillance programs in different countries. In conclusion, the prevalence of clarithromycin- and metronidazole-resistant $H$. pylori is high in most SEA countries and will continue to rise in the future if intervention strategies are not adopted. While the resistance rates to amoxicillin and tetracycline are still low, there is a need for the development of an intervention strategy by policymakers to guide clinicians and respective bodies in this region to encourage research and discovery of new antimicrobial agents for the treatment of $H$. pylori. More research collaboration among SEA countries should be conducted for this matter, with harmonization of data and an understanding of any successful intervention strategies in specific countries.

\section{Methods}

\subsection{Search Strategy and Study Selection}

In the systematic review of antibiotic resistance in SEAC, we searched the potential research articles through electronic databases, namely PubMed, Scopus, Medline, and Science Direct, from 1 January 1990 to 1 May 2021. The electronic search was conducted on 6 May 2021. Additionally, we manually searched the articles by checking references 
from review and research articles relevant to our research questions. Details on specific keywords used for our search strategy using electronic databases are as follows:

(("Helicobacter pylori”) AND ("antibiotic" OR “antimicrobial” OR "anti-microbial” OR "antibacterial" OR "anti-bacterial" OR "drug") AND ("resistance" OR "resistant") AND ("Malaysia" OR "Singapore" OR "Thailand" OR "Indonesia" OR "Brunei" OR "Myanmar" OR "Vietnam" OR “Timor Leste" OR “Laos" OR “Cambodia" OR "Philippines")).

This systematic review was prepared according to Preferred Reporting Items for Systematic Reviews and Meta-Analysis (PRISMA) guidelines [48]. We included studies performed on populations in SEAC as defined by the United Nations [49]. These countries include Malaysia, Thailand, Singapore, Brunei Darussalam, Indonesia, Myanmar, Cambodia, Laos, Vietnam, and Philippines. Studies performed on populations outside SEA countries or studies without a clear population description were excluded from this systematic review. We also excluded studies conducted on children.

All study types were included in our search. However, we restricted our search to publications in English only. Abstracts without full text, all types of reviews, letters to the editors, and conference posters or presentations were excluded from our study. We included studies that measured the prevalence of primary antibiotic resistance for the following antibiotics: Metronidazole, clarithromycin, amoxicillin, tetracycline, and levofloxacin. Exclusion criteria were: (1) Studies that measured the prevalence of alternative antibiotics for H. pylori treatment; (2) studies that reported prevalence results using less than 50 isolates for culture method or less than $50 \mathrm{H}$. pylori positive gastric biopsies for nucleic acid-based method; (3) studies that only reported the percentage of resistance rates with no description of the number of isolates used; (4) studies with no time frame of sample collection; (5) studies that clustered prevalence rates data more than three years; (6) studies that failed to state the percentage of primary antibiotic resistance in H. pylori isolates examined; and (7) studies that only examined the prevalence of resistance rate of secondary isolates. If duplicate studies reported prevalence data using similar H. pylori cohorts, only the first study conducted on antibiotic resistance prevalence was chosen to be included in our systematic review.

\subsection{Definitions of Diagnostic Tools and Antibiotic Resistance}

Patients were defined as $H$. pylori-infected if they tested positive using one of the following diagnostic tools: Urea breath test, histopathological examination, culture-based test, rapid urease test of biopsies, and nucleic acid-based test. Antibiotic susceptibility tests include culture-based methods (E-test and the agar dilution method), or the nucleic acid-based test performed on $\mathrm{H}$. pylori isolates or directly from gastric biopsies. Primary resistance was defined as $H$. pylori resistance to any antibiotics prior to administration of treatment regimens. Multidrug resistance in $\mathrm{H}$. pylori is defined as H. pylori resistant to two or more antimicrobial agents. The threshold of high antibiotic resistance is a rate of more than $15 \%[6]$.

\subsection{Data Extraction}

Two independent reviewers independently screened the eligibility of articles from our search strategy through a two-step process. First, the articles were screened for title and abstracts for relevancy to our review. The full texts were retrieved and evaluated for the articles that passed the title and abstract screening process. Disagreement on inclusion or exclusion of the articles into the review was resolved through discussion and consensus. Data extracted from included studies were authors, country, year, period of sample collection, study design, patients' clinical information (sample size, age, sex, histological findings, diseases, and H. pylori infection diagnostic tool used), and H. pylori samples (sample size, number of resistances, type of tested samples, the method to detect antibiotic resistance, and breakpoint system used). All data were extracted and sorted into Microsoft Office Excel 2016. 


\subsection{Quality Assessment of Studies}

The quality of included studies was assessed as previously described [50], in which the score of study quality ranged from 0 to 8 . A study with a score $>5$ was considered as high quality while a study with a score that ranged $4-5$ was considered as medium quality. Finally, a study with a score less than 4 was considered as low quality and would be excluded from this systematic review. Two reviewers independently scored each included article and any inconsistency on score result was resolved through discussion for final consensus.

\subsection{A Narrative Review on AMP Studies in H. pylori}

We searched through electronic literature databases on the studies using AMP in H. pylori treatment and summarized the findings.

Author Contributions: Conceptualization, A.S., B.S.L. and A.H.; methodology, A.S. and A.H.; validation, A.S., B.S.L. and A.H.; formal analysis, A.S.; writing—original draft preparation, A.S.; writingreview and editing, A.S., B.S.L. and A.H.; supervision, A.H. All authors have read and agreed to the published version of the manuscript.

Funding: This study was supported by a grant from Ministry of Higher Education of Malaysia, grant no. FRGS/1/2019/SKK11/UKM/02/3 and Universiti Teknologi MARA (UiTM) under grant no. 600-RMC/DINAMIK-POSTDOC 5/3 (010/2020).

Institutional Review Board Statement: Not applicable.

Informed Consent Statement: Not applicable.

Data Availability Statement: All data searched and extracted from the included studies in this systematic review are available upon request to corresponding author.

Conflicts of Interest: The authors declare no conflict of interest.

\section{References}

1. Hooi, J.K.Y.; Lai, W.Y.; Ng, W.K.; Suen, M.M.Y.; Underwood, F.E.; Tanyingoh, D.; Malfertheiner, P.; Graham, D.Y.; Wong, V.W.S.; Wu, J.C.Y.; et al. Global prevalence of Helicobacter pylori infection: Systematic review and meta-analysis. Gastroenterology 2017, 153, 420-429. [CrossRef] [PubMed]

2. Kayali, S.; Manfredi, M.; Gaiani, F.; Bianchi, L.; Bizzarri, B.; Leandro, G.; Di Mario, F.; De'Angelis, G.L. Helicobacter pylori, transmission routes and recurrence of infection: State of the art. Acta Biomed. 2018, 89, 72-76. [PubMed]

3. Sukri, A.; Hanafiah, A.; Mohamad Zin, N.; Kosai, N.R. Epidemiology and role of Helicobacter pylori virulence factors in gastric cancer carcinogenesis. APMIS 2020, 128, 150-161. [CrossRef]

4. Sung, H.; Ferlay, J.; Siegel, R.L.; Laversanne, M.; Soerjomataram, I.; Jemal, A.; Bray, F. Global Cancer Statistics 2020: GLOBOCAN estimates of incidence and mortality worldwide for 36 cancers in 185 countries. CA Cancer J. Clin. 2021, 71, 209-249. [CrossRef]

5. Rugge, M.; Fassan, M.; Graham, D. Epidemiology of Gastric Cancer. In Gastric Cancer; Strong, V.E., Ed.; Springer: Cham, Switzerland, 2015; pp. 23-34.

6. Malfertheiner, P.; Megraud, F.; O’Morain, C.A.; Gisbert, J.P.; Kuipers, E.J.; Axon, A.T.; Bazzoli, F.; Gasbarrini, A.; Atherton, J.; Graham, D.Y.; et al. European Helicobacter and Microbiota Study Group and Consensus panel. Management of Helicobacter pylori infection-the Maastricht V/Florence Consensus Report. Gut 2017, 66, 6-30. [CrossRef] [PubMed]

7. Savoldi, A.; Carrara, E.; Graham, D.Y.; Conti, M.; Tacconelli, E. Prevalence of antibiotic resistance in Helicobacter pylori: A systematic review and meta-analysis in World Health Organization regions. Gastroenterology 2018, 155, 1372-1382.e17. [CrossRef] [PubMed]

8. Tacconelli, E.; Carrara, E.; Savoldi, A.; Harbarth, S.; Mendelson, M.; Monnet, D.L.; Pulcini, C.; Kahlmeter, G.; Kluytmans, J.; Carmeli, Y.; et al. Discovery, research, and development of new antibiotics: The WHO priority list of antibiotic-resistant bacteria and tuberculosis. Lancet Infect. Dis. 2018, 18, 318-327. [CrossRef]

9. The World Bank. Available online: https://datahelpdesk.worldbank.org/knowledgebase/articles/906519-world-bank-countryand-lending-groups (accessed on 29 June 2021).

10. Hughes, A. Understanding the drivers of Southeast Asian biodiversity loss. Ecosphere 2017, 8, e01624. [CrossRef]

11. Chen, C.H.; Lu, T.K. Development and challenges of antimicrobial peptides for therapeutic applications. Antibiotics 2020, 9, 24. [CrossRef]

12. Biswaro, L.S.; da Costa Sousa, M.G.; Rezende, T.M.B.; Dias, S.C.; Franco, O.L. Antimicrobial peptides and nanotechnology, recent advances and challenges. Front. Microbiol 2018, 9, 855. [CrossRef] [PubMed] 
13. Auttajaroon, J.; Chotivitayatarakorn, P.; Yamaoka, Y.; Vilaichone, R.K. CYP2C19 Genotype, CagA genotype and antibiotic resistant strain of Helicobacter pylori infection. Asian Pac. J. Cancer Prev. 2019, 20, 1243-1247. [CrossRef]

14. Vilaichone, R.K.; Ratanachu ek, T.; Gamnarai, P.; Subsomwong, P.; Uchida, T.; Yamaoka, Y.; Mahachai, V. High fluoroquinolone resistant strains of Helicobacter pylori in the Golden triangle. Asian Pac. J. Cancer Prev. 2017, 18, 455-458. [PubMed]

15. Vilaichone, R.K.; Ratanachu ek, T.; Gamnarai, P.; Chaithongrat, S.; Uchida, T.; Yamaoka, Y.; Mahachai, V. Extremely high prevalence of metronidazole-resistant Helicobacter pylori strains in mountain people (Karen and Hmong) in Thailand. Am. J. Trop Med. Hyg. 2016, 94, 717-720. [CrossRef]

16. Vilaichone, R.K.; Mahacahai, V.; Tumwasorn, S.; Kachintorn, U. CagA genotype and metronidazole resistant strain of Helicobacter pylori in functional dyspepsia in Thailand. J. Gastroenterol. Hepatol. 2011, 26 (Suppl. S3), 46-48. [CrossRef] [PubMed]

17. Tongtawee, T.; Dechsukhum, C.; Matrakool, L.; Panpimanmas, S.; Loyd, R.A.; Kaewpitoon, S.J.; Kaewpitoon, N. High Prevalence of Helicobacter pylori resistance to clarithromycin: A hospital-based cross-sectional study in Nakhon Ratchasima Province, Northeast of Thailand. Asian Pac. J. Cancer Prev. 2015, 16, 8281-8285. [CrossRef]

18. Tuan, V.P.; Narith, D.; Tshibangu-Kabamba, E.; Dung, H.D.Q.; Viet, P.T.; Sokomoth, S.; Binh, T.T.; Sokhem, S.; Tri, T.D.; Ngov, S.; et al. A next-generation sequencing-based approach to identify genetic determinants of antibiotic resistance in Cambodian Helicobacter pylori clinical isolates. J. Clin. Med. 2019, 8, 858. [CrossRef]

19. Miftahussurur, M.; Syam, A.F.; Nusi, I.A.; Makmun, D.; Waskito, L.A.; Zein, L.H.; Akil, F.; Uwan, W.B.; Simanjuntak, D.; Wibawa, I.D.; et al. Surveillance of Helicobacter pylori antibiotic susceptibility in Indonesia: Different resistance types among regions and with novel genetic mutations. PLoS ONE 2016, 11, e0166199. [CrossRef]

20. Vannarath, S.; Vilaichone, R.K.; Rasachak, B.; Mairiang, P.; Yamaoka, Y.; Mahachai, V. Antibiotic resistant pattern of Helicobacter pylori infection based on molecular tests in Laos. Asian Pac. J. Cancer Prev. 2016, 17, 285-287. [CrossRef] [PubMed]

21. Hanafiah, A.; Binmaeil, H.; Raja Ali, R.A.; Mohamed Rose, I.; Lopes, B.S. Molecular characterization and prevalence of antibiotic resistance in Helicobacter pylori isolates in Kuala Lumpur, Malaysia. Infect. Drug Resist. 2019, 12, 3051-3061. [CrossRef] [PubMed]

22. Goh, K.L.; Navaratnam, P. High Helicobacter pylori resistance to metronidazole but zero or low resistance to clarithromycin, levofloxacin, and other antibiotics in Malaysia. Helicobacter 2011, 16, 241-245. [CrossRef]

23. Ahmad, N.; Zakaria, W.R.; Mohamed, R. Analysis of antibiotic susceptibility patterns of Helicobacter pylori isolates from Malaysia Helicobacter 2011, 16, 47-51. [CrossRef] [PubMed]

24. Ang, T.L.; Fock, K.M.; Song, M.; Ang, D.; Kwek, A.B.; Ong, J.; Tan, J.; Teo, E.K.; Dhamodaran, S. Ten-day triple therapy versus sequential therapy versus concomitant therapy as first-line treatment for Helicobacter pylori infection. J. Gastroenterol. Hepatol. 2015, 30, 1134-1139. [CrossRef]

25. Dang, N.Q.H.; Ha, T.M.T.; Nguyen, S.T.; Le, N.D.K.; Nguyen, T.M.T.; Nguyen, T.H.; Pham, T.T.H.; Tran, V.H. High rates of clarithromycin and levofloxacin resistance of Helicobacter pylori in patients with chronic gastritis in the south east area of Vietnam. J. Glob. Antimicrob. Resist. 2020, 22, 620-624. [CrossRef]

26. Binh, T.T.; Shiota, S.; Nguyen, L.T.; Ho, D.D.; Hoang, H.H.; Ta, L.; Trinh, D.T.; Fujioka, T.; Yamaoka, Y. The incidence of primary antibiotic resistance of Helicobacter pylori in Vietnam. J. Clin. Gastroenterol. 2013, 47, 233-238. [CrossRef] [PubMed]

27. Phan, T.N.; Santona, A.; Tran, V.H.; Tran, T.N.; Le, V.A.; Cappuccinelli, P.; Rubino, S.; Paglietti, B. High rate of levofloxacin resistance in a background of clarithromycin- and metronidazole-resistant Helicobacter pylori in Vietnam. Int. J. Antimicrob. Agents 2015, 45, 244-248. [CrossRef]

28. Zhang, L.; Wu, W.K.; Gallo, R.L.; Fang, E.F.; Hu, W.; Ling, T.K.; Shen, J.; Chan, R.L.; Lu, L.; Luo, X.M.; et al. Critical role of antimicrobial peptide cathelicidin for controlling Helicobacter pylori survival and infection. J. Immunol. 2016, 196, 1799-1809. [CrossRef]

29. Guzman, J.; Téné, N.; Touchard, A.; Castillo, D.; Belkhelfa, H.; Haddioui-Hbabi, L.; Treilhou, M.; Sauvain, M. Anti-Helicobacter pylori properties of the ant-venom peptide bicarinalin. Toxins 2017, 10, 21. [CrossRef]

30. Chen, L.; Li, Y.; Li, J.; Xu, X.; Lai, R.; Zou, Q. An antimicrobial peptide with antimicrobial activity against Helicobacter pylori. Peptides 2007, 28, 1527-1531. [CrossRef]

31. Narayana, J.L.; Huang, H.N.; Wu, C.J.; Chen, J.Y. Efficacy of the antimicrobial peptide TP4 against Helicobacter pylori infection: In vitro membrane perturbsation via micellization and in vivo suppression of host immune responses in a mouse model. Oncotarget 2015, 6, 12936-12954. [CrossRef]

32. Wang, X.; Song, Y.; Li, J.; Liu, H.; Xu, X.; Lai, R.; Zhang, K. A new family of antimicrobial peptides from skin secretions of Rana pleuraden. Peptides 2007, 28, 2069-2074. [CrossRef] [PubMed]

33. Jiang, M.; Ma, L.; Huang, Y.; Wu, H.; Dou, J.; Zhou, C. Antimicrobial activities of peptide Cbf-K16 against drug-resistant Helicobacter pylori infection in vitro and in vivo. Microb. Pathog. 2020, 138, 103847. [CrossRef]

34. Zhang, X.L.; Jiang, A.M.; Ma, Z.Y.; Li, X.B.; Xiong, Y.Y.; Dou, J.F.; Wang, J.F. The synthetic antimicrobial peptide pexiganan and its nanoparticles (PNPs) exhibit the anti-helicobacter pylori activity in vitro and in vivo. Molecules 2015, 20, 3972-3985. [CrossRef]

35. Narayana, J.L.; Huang, H.N.; Wu, C.J.; Chen, J.Y. Epinecidin-1 antimicrobial activity: In vitro membrane lysis and in vivo efficacy against Helicobacter pylori infection in a mouse model. Biomaterials 2015, 61, 41-51. [CrossRef]

36. Xiong, M.; Bao, Y.; Xu, X.; Wang, H.; Han, Z.; Wang, Z.; Liu, Y.; Huang, S.; Song, Z.; Chen, J.; et al. Selective killing of Helicobacter pylori with $\mathrm{pH}$-responsive helix-coil conformation transitionable antimicrobial polypeptides. Proc. Natl. Acad. Sci. USA 2017, 114, 12675-12680. [CrossRef] 
37. Zhang, X.; Jiang, A.; Qi, B.; Yu, H.; Xiong, Y.; Zhou, G.; Qin, M.; Dou, J.; Wang, J. Secretion expression of human neutrophil peptide 1 (HNP1) in Pichia pastoris and its functional analysis against antibiotic-resistant Helicobacter pylori. Appl. Microbiol. Biotechnol. 2018, 102, 4817-4827. [CrossRef] [PubMed]

38. Zhang, X.; Jiang, A.; Wang, G.; Yu, H.; Qi, B.; Xiong, Y.; Zhou, G.; Qin, M.; Dou, J.; Wang, J. Fusion expression of the PGLa-AM1 with native structure and evaluation of its anti-Helicobacter pylori activity. Appl. Microbiol. Biotechnol. 2017, 101, 5667-5675. [CrossRef]

39. Makobongo, M.O.; Gancz, H.; Carpenter, B.M.; McDaniel, D.P.; Merrell, D.S. The oligo-acyl lysyl antimicrobial peptide $C_{12} K_{-2} \beta_{12}$ exhibits a dual mechanism of action and demonstrates strong in vivo efficacy against Helicobacter pylori. Antimicrob. Agents Chemother. 2012, 56, 378-390. [CrossRef] [PubMed]

40. Rigano, M.M.; Romanelli, A.; Fulgione, A.; Nocerino, N.; D’Agostino, N.; Avitabile, C.; Frusciante, L.; Barone, A.; Capuano, F.; Capparelli, R. A novel synthetic peptide from a tomato defensin exhibits antibacterial activities against Helicobacter pylori. J. Pept. Sci. 2012, 18, 755-762. [CrossRef]

41. Iwahori, A.; Hirota, Y.; Sampe, R.; Miyano, S.; Takahashi, N.; Sasatsu, M.; Kondo, I.; Numao, N. On the antibacterial activity of normal and reversed magainin 2 analogs against Helicobacter pylori. Biol. Pharm. Bull. 1997, 20, 805-808. [CrossRef]

42. Kuo, Y.T.; Liou, J.M.; El-Omar, E.M.; Wu, J.Y.; Leow, A.H.R.; Goh, K.L.; Das, R.; Lu, H.; Lin, J.T.; Tu, Y.K.; et al. Asian Pacific Alliance on Helicobacter and Microbiota. Primary antibiotic resistance in Helicobacter pylori in the Asia-Pacific region: A systematic review and meta-analysis. Lancet Gastroenterol. Hepatol. 2017, 2, 707-715. [CrossRef]

43. Hernández Ceruelos, A.; Romero-Quezada, L.C.; Ruvalcaba Ledezma, J.C.; López Contreras, L. Therapeutic uses of metronidazole and its side effects: An update. Eur. Rev. Med. Pharmacol. Sci. 2019, 23, 397-401.

44. Mahachai, V.; Vilaichone, R.K.; Pittayanon, R.; Rojborwonwitaya, J.; Leelakusolvong, S.; Maneerattanaporn, M.; Chotivitayatarakorn, P.; Treeprasertsuk, S.; Kositchaiwat, C.; Pisespongsa, P.; et al. Helicobacter pylori management in ASEAN: The Bangkok consensus report. J. Gastroenterol. Hepatol. 2018, 33, 37-56. [CrossRef]

45. Levy, S.B. The 2000 Garrod lecture. Factors impacting on the problem of antibiotic resistance. J. Antimicrob. Chemother. 2002, 49, 25-30. [CrossRef]

46. Losurdo, G.; Leandro, G.; Principi, M.; Giorgio, F.; Montenegro, L.; Sorrentino, C.; Ierardi, E.; Di Leo, A. Sequential vs. prolonged 14-day triple therapy for Helicobacter pylori eradication: The meta-analysis may be influenced by 'geographical weighting'. Int. J. Clin. Pract. 2015, 69, 1112-1120. [CrossRef] [PubMed]

47. Tang, Y.; Tang, G.; Pan, L.; Zhu, H.; Zhou, S.; Wei, Z. Clinical factors associated with initial Helicobacter pylori eradication therapy: A retrospective study in China. Sci. Rep. 2020, 10, 15403. [CrossRef] [PubMed]

48. PRISMA. Available online: http:/ / www.prisma-statement.org/ (accessed on 1 May 2021).

49. United Nations. Available online: https://www.un.org/press/en/2020/sc14093.doc.htm (accessed on 29 June 2021).

50. Munn, Z.; Moola, S.; Riitano, D.; Lisy, K. The development of a critical appraisal tool for use in systematic reviews addressing questions of prevalence. Int. J. Health Policy Manag. 2014, 3, 123-128. [CrossRef] [PubMed] 